\title{
Prevalence of Obesity and Overweight among Primary Schools Children in Qena, Egypt \\ Amira M.M. Hamed ${ }^{1}$, Alaa-Eldin A. Hassan ${ }^{1}$, Mohammed Mahmoud Sayed Younis ${ }^{1}$, Al-Mostafa Mohammed Kamal ${ }^{* 2}$ \\ ${ }^{1}$ Faculty of Medicine, Department of Pediatrics, Al-Azhar University, Assuit branch, Egypt \\ ${ }^{2}$ Qeft Teaching Hospital, Ministry of Health, Qena, Egypt \\ *Corresponding author: Al-Mostafa Mohammed Kamal, Email: almostafa.kamal99@ gmail.com,
} Mobile: (+20) 1226020554

\begin{abstract}
Background: Obesity is a significant public health concern affecting more than half a billion people worldwide giving rise to a range of health problems. This is due to its various and serious health hazards on one side and its preventable nature on the other side. Objective: This study aimed at identification of prevalence of overweight and obesity and its risk factors among children between 6 - 12 years of age in Qena, Egypt.

Methods and populations: A cross sectional study was conducted on 1000 students were chosen randomly from all grades of primary schools (6 -12 years) in the period from January, 2019 to June, 2019.

Results: The overall prevalence of obesity and overweight was $13.9 \%$ and $16.2 \%$ respectively. Girls were more obese than boys, $(\mathrm{OR}=7.26,95 \% \mathrm{CI}: 4.6-10.19)$. Current study revealed that $71.2 \%$ of the obese and 66.7 of overweight children were from urban areas (OR=0.172, $95 \%$ CI: $0.115-0.257)$ and $38.5 \%$ of the overweight children and $97.2 \%$ of the obese children had an obese parent $(\mathrm{OR}=134.4,95 \% \mathrm{CI}: 47.06$ - 372.6). There was a statistical significant association between prevalence of overweight and obesity in school children and education of the mother $(\mathrm{OR}=10.2$, 95\% CI: 6.2-16.6).

Conclusion: About one out of seven of 6-12 year-old-children in Qena city were obese. Locality of residence, gender, guardian education, obese guardian, feeding formula in early life, bad dietary habit (fast food consumption and missed breakfast) and lack of physical activity were likely to be the predictors of this alarming issue.
\end{abstract}

Key words: Childhood, Overweight, Obesity.

\section{INTRODUCTION}

Obesity is a significant public health concern affecting more than half a billion people worldwide ${ }^{(\mathbf{1})}$. In 2018, more than 1.9 billion were overweight and 600 million were obese. $39 \%$ of children and adolescents less than 18 years were overweight in 2018 and 13\% were obese. More than 41 million children under the age of 5 years were overweight or obese in 2018. In Egypt, the estimated prevalence of overweight increased from $4 \%$ in 1990 to $7 \%$ in 2011 and is expected to increase ${ }^{(2)}$. In Port Said city the overall prevalence of overweight and obesity in governmental pupils (6-12 years old) was $17.7 \%$ and $13.5 \%$ respectively ${ }^{(3)}$. In Cairo, the overweight and obesity prevalence was $11 \%$ and $3.8 \%$ respectively ${ }^{(4)}$. In Alexandria the overall prevalence of overweight and obesity in governmental pupils (6-12 years old) is 16.8 and $9 \%$ respectively (5). In El-Sharkia, overall prevalence of overweight and obesity showed $20 \%$ for overweight and $10.7 \%$ for obesity ${ }^{(6)}$. In Assuit city, the overall prevalence of overweight and obesity among primary school children aged from 6 to 11 years was $11.24 \%$ and $12.28 \%$ respectively ${ }^{(7)}$. Obesity is often defined simply as a condition of abnormal or excessive fat accumulation in adipose tissue, to the extent that health may be impaired ${ }^{(8)}$.

The BMI-for age percentile has been used as a reliable and accurate estimate for body fatness in children and adolescents. BMI-for age $\geq 85 \%$ percentile is considered overweight. BMI-for age $\geq 95 \%$, percentile is considered obese ${ }^{(9)}$. Skinfold thickness is useful for describing subcutaneous body fat distribution or "fat patterning" (10). Obese children and adolescents have been shown to be more likely to skip breakfast and consume a few large meals per day than their leaner counterparts who are more likely to consume smaller frequent meals ${ }^{(\mathbf{1 1})}$. Most of children who miss breakfast will easy to weight gain. Conversely, breakfast consumption is an important factor to determine the quality of diet and energy intake that affect school children health status ${ }^{(\mathbf{1 2})}$.

Reported associations of food groups with childhood obesity include low intake of fruits and vegetables, high intake of fast foods and sweets and high intake of sugar-sweetened beverages such as soft drinks ${ }^{(13)}$. Snacks tend to be higher in energy density and fat content than meals and high snack consumption has been associated with high intake of fat and sugar (14). Increasing body weight increases mortality because of coronary heart diseases risk. The risk of developing DM and some types of cancers increase with obesity (15). Parents must be more aware of the role they can play in preventing obesity in their children ${ }^{(16)}$. The earliest school-based obesity interventions are based on the program that was conducted during school hours. This program consisted of intensive exercise and nutrition education program delivered over a 5-6 month period $^{(\mathbf{1 7})}$.

\section{AIM OF THE WORK}

This study aimed at identification of prevalence of overweight and obesity and its risk factors among children between 6 - 12 years of age in Qena, Egypt. 


\section{PATIENTS AND METHODS}

Study Design and Setting: This cross-sectional school-based study was conducted in four primary schools in Qena city. 1000 students were chosen randomly. It was conducted through a period of six months from January, 2019 to June, 2019.

Sample Size: The sample size was calculated using the EPI-INFO 2002 software (Centers for Disease Control and Prevention (CDC), Atlanta, Georgia, USA; on the basis of a prevalence rate of $13.3 \%$ for obesity among primary school children ${ }^{(3)}$. With a precision of $3 \%$, a confidence level of $95 \%$, and an error of 0.05 , a minimum sample of 450 students were required. This sample was increased to 1000 for proper representation of different age groups in the selected schools.

Sampling Technique and Procedures: Stratified and clustered random sampling technique was employed to select study subjects. Stratification was based on grades and location of the school. 250 students from each school, in Qena city, 40 students from the first 5 grades and 50 students from $6^{\text {th }}$ grade. 4 schools were enrolled in this study. As regards the gender all the selected primary and preparatory schools included both girls and boys. All students aged between 6 to12 years were included, while students less than 6 years or more than 12 years were excluded. Also children with chronic illness as well as those on corticosteroid therapy or growth hormone replacement therapy were excluded.

Data Collection Procedure: After agreement of the head of educational directorate of Qena governorate on conducting this research, data were collected from January, 2019 to June, 2019. In the first visit to each school, the researcher invited children to participate in the study, sampled them and gave them consent letter for their parents that included basic information about aim of the study, the planned physical examination of the study participants and the questionnaire. This visit took place a day before the second visit in which data were collected. On arrival of the second visit, consent letters from the parents were collected from the children and those who were allowed to participate in the research were gathered in class for anthropometric measurements, then they were given the questionnaire and were asked to take it home to be filled by their parents and give it back to the researcher on the next day.

\section{Instrument of the Study}

Questionnaire: A semi-structured, selfadministered questionnaire was used. The questionnaire had two sections; the first section that was filled in the school by the researcher included personal informations: age, grade, gender, school name in addition to anthropometric measurements. The second section, which is a reliable questionnaire was filled by one of the parents. This section concerned about the suggested risk factors of overweight and obesity including maternal education and job, maternal or parental obesity (documented by the mother herself), birth weight of the child and type of feeding during infancy (whether breast, formula feeding or both). Data about the current dietary habits of the child were also collected including frequency of eating fast food, frequency of drinking sugary fruit juice daily, frequency of eating fresh vegetables and fruits in addition to information about the weekly practice of physical exercises.

\section{Anthropometric Measurements:}

The study groups were examined for anthropometric measurements using similar techniques for obese and non-obese students by two well-trained persons (male for boys and female for girls) under supervision of the investigator. Body weight (in kilograms) was measured by a standardized balanced digital scale to the nearest 0.5 . Height (in centimeters) was measured by a standardized fixed stadiometer fixed vertically on the wall. BMI for-age and sex percentiles are one of the most reliable, known and useful anthropometric measurements for the assessment of obesity in children and adolescents ${ }^{(\mathbf{1 8})}$. BMI was estimated by dividing the weight in $\mathrm{kg}$ on square of height in meter. The results were applied separately for every student and classified by plotting BMI against standard percentile Egyptian curves for each age and sex into: underweight, normal weight, overweight and obese ${ }^{(\mathbf{1 9})}$. Underweight: less than the 5th percentile, normal weight: 5 th percentile to less than the 85th percentile, overweight: 85th to less than the 95th percentile and obese: 95 th percentile or greater.

Ethical Consideration: The study protocol was approved by ethical committee of the Faculty of Medicine, Al-Azhar University - Assuit branch. A prior consent for the study was taken from the school administration. At the time of the study the parents of each participant were informed about the study protocol and a written consent was obtained to their child's participation and confidentiality was assured.

\section{Statistical Analysis}

Statistical analysis was done by compatible computer using software SPSS version 20 for windows. Frequencies, descriptive statistics, correlation, $\mathrm{X}^{2}$ test, t-test and regression analysis were done along with the respective odds ratios for obesity with their $95 \%$ (CIs). Chi-square test and fisher exact test was used to compare between categorical variables while for comparing between continuous variables, we used Independent-Samples $\mathrm{T}$ test and ANOVA. The probability of less than 0.05 was used as cut off point for all significant tests. 


\section{RESULTS}

Table (1): Socio-demographic characteristics and nutritional status among studied children

\begin{tabular}{|c|c|c|c|c|}
\hline Variable & $\begin{array}{c}\text { Normal weight } \\
(n=699) \\
\text { No } \%\end{array}$ & $\begin{array}{c}\text { Overweight } \\
\begin{array}{c}(n=162) \\
\text { No } \%\end{array}\end{array}$ & $\begin{array}{c}\text { Obese } \\
(n=139) \\
\text { No } \%\end{array}$ & $P$ value \\
\hline $\begin{array}{c}\text { Age: } \\
6- \\
7- \\
8- \\
-9 \\
10- \\
11-\end{array}$ & $\begin{array}{c}125(17.9 \%) \\
114(16.3 \%) \\
120(17.2 \%) \\
117(16.7 \%) \\
116(16.6 \% \\
107(15.3 \%)\end{array}$ & $\begin{array}{l}22(13.6 \%) \\
28(17.3 \%) \\
25(15.4 \%) \\
27(16.7 \%) \\
28(17.3 \%) \\
32(19.8 \%)\end{array}$ & $\begin{array}{l}20(14.4 \%) \\
25(17.9 \%) \\
22(15.8 \%) \\
23(16.6 \%) \\
23(16.6 \%) \\
26(18.7 \%)\end{array}$ & 0.87 \\
\hline $\begin{array}{l}\text { Gender: } \\
\text { Boys } \\
\text { Girls }\end{array}$ & $\begin{array}{l}285(40.8 \%) \\
414(59.2 \%)\end{array}$ & $\begin{array}{l}70(43.2 \%) \\
92(56.8 \%)\end{array}$ & $\begin{array}{l}62(44.6 \%) \\
77(55.4 \%)\end{array}$ & 0.016 \\
\hline $\begin{array}{l}\text { Residence: } \\
\text { Rural } \\
\text { Urban }\end{array}$ & $\begin{array}{l}490(70.1 \%) \\
209(29.9 \%)\end{array}$ & $\begin{array}{c}54(33.3 \%) \\
108(66.7 \%)\end{array}$ & $\begin{array}{l}40(28.8 \%) \\
99(71.2 \%)\end{array}$ & 0.001 \\
\hline $\begin{array}{l}\text { Education of the mother: } \\
\text { High } \\
\text { Preparatory } \\
\text { Primary }\end{array}$ & $\begin{array}{c}450(64.3 \%) \\
150(21.5 \%) \\
99(14.2 \%)\end{array}$ & $\begin{array}{l}40(24.7 \%) \\
98(60.5 \%) \\
24(14.8 \%)\end{array}$ & $\begin{array}{l}21(15.1 \%) \\
70(50.4 \%) \\
48(34.5 \%)\end{array}$ & 0.001 \\
\hline $\begin{array}{l}\text { Job of the mother: } \\
\text { House wife } \\
\text { Working mother }\end{array}$ & $\begin{array}{l}260(37.2 \%) \\
439(62.8 \%)\end{array}$ & $\begin{array}{c}50(30.9 \%) \\
112(69.1 \%)\end{array}$ & $\begin{array}{l}45(32.4 \%) \\
94(67.6 \%)\end{array}$ & 0.112 \\
\hline $\begin{array}{l}\text { Obesity among parents: } \\
\text { No obesity } \\
\text { Father only } \\
\text { Mother only } \\
\text { Both parents }\end{array}$ & $\begin{array}{c}430(61.5 \%) \\
110(15.7 \%) \\
90(12.9 \%) \\
69(9.9 \%)\end{array}$ & $\begin{array}{c}7(4.3 \%) \\
30(18.5 \%) \\
45(27.8 \%) \\
80(49.4 \%)\end{array}$ & $\begin{array}{c}4(2.8 \%) \\
20(14.4 \%) \\
30(21.6 \%) \\
85(61.2 \%)\end{array}$ & 0.001 \\
\hline
\end{tabular}

Table (1) shows significant relationship between developing of Obesity and ( Residence, parental obesity, and maternal education).

Table (2): Nutritional status, feeding in early life and dietary habits among studied children

\begin{tabular}{|c|c|c|c|c|}
\hline Variable & $\begin{array}{c}\text { Normal weight } \\
(\mathbf{n}=699) \\
\text { No } \%\end{array}$ & $\begin{array}{c}\text { Overweight } \\
\begin{array}{c}(\mathrm{n}=162) \\
\text { No } \%\end{array}\end{array}$ & $\begin{array}{c}\text { Obese } \\
(n=139) \\
\text { No } \%\end{array}$ & $P$ value \\
\hline $\begin{array}{l}\text { Feeding in early life: } \\
\text { Breast feeding } \\
\text { Formula feeding } \\
\text { Both breast and formula feeding }\end{array}$ & $\begin{array}{c}620(88.7 \%) \\
39(5.6 \%) \\
40(5.7 \%)\end{array}$ & $\begin{array}{l}42(25.9 \%) \\
62(38.3 \%) \\
58(35.8 \%)\end{array}$ & $\begin{array}{l}22(15.8 \%) \\
50(36 \%) \\
67(48.2 \%)\end{array}$ & 0.001 \\
\hline $\begin{aligned} \text { Weekly Fast food consumption: } & \text { Yes } \\
& \text { No }\end{aligned}$ & $\begin{array}{l}97(13.9 \%) \\
602(86.2 \%)\end{array}$ & $\begin{array}{l}92(56.8 \%) \\
70(43.2 \%)\end{array}$ & $\begin{array}{l}73(52.5 \%) \\
66(47.5 \%)\end{array}$ & 0.000 \\
\hline Breakfast intake: & $\begin{array}{l}480(68.7 \%) \\
219(31.3 \%)\end{array}$ & $\begin{array}{l}75(46.3 \%) \\
87(53.7 \%)\end{array}$ & $\begin{array}{l}50(36 \%) \\
89(64 \%)\end{array}$ & 0.001 \\
\hline $\begin{array}{l}\text { Weekly Fresh vegetables \& fruits } \\
\text { consumption: } \\
\text { Once } \\
\text { Twice } \\
\text { More than twice }\end{array}$ & $\begin{array}{c}144(20.6 \%) \\
135(19.3 \%) \\
420(60.1 \%)\end{array}$ & $\begin{array}{r}110(67.9 \%) \\
32(19.8 \%) \\
20(12.3 \%)\end{array}$ & $\begin{array}{l}90(64.7 \%) \\
34(24.5 \%) \\
15(10.8 \%)\end{array}$ & 0.001 \\
\hline
\end{tabular}

Table (2) shows significant relationship between developing of Obesity and (feeding in early life, fast food intake, fresh fruits and vegetables intake and breakfast intake). 
Table (3): Nutritional status, physical activity and daily habits among studied children

\begin{tabular}{|c|c|c|c|c|}
\hline Variable & $\begin{array}{c}\text { Normal weight } \\
(\mathbf{n}=699) \\
\text { No \% }\end{array}$ & $\begin{array}{l}\text { Overweight } \\
(\mathbf{n}=162) \\
\text { No \% }\end{array}$ & $\begin{array}{c}\text { Obese } \\
(\mathbf{n}=139) \\
\text { No } \%\end{array}$ & $P$ value \\
\hline $\begin{array}{l}\text { Transportation to school: } \\
\text { Walking } \\
\text { Bicycle } \\
\text { General transportation } \\
\text { Taxi or car }\end{array}$ & $\begin{array}{l}550(78.7 \%) \\
65(9.1 \%) \\
55(7.9 \%) \\
29(4.1 \%)\end{array}$ & $\begin{array}{l}8(4.9 \%) \\
4(2.5 \%) \\
12(7.4 \%) \\
138(85.2 \%)\end{array}$ & $\begin{array}{l}9(6.5 \%) \\
5(3.5 \%) \\
10(7.2 \%) \\
115(82.7 \%)\end{array}$ & 0.047 \\
\hline $\begin{array}{r}\text { Performing physical activity: Yes } \\
\text { No }\end{array}$ & $\begin{array}{l}574(82.1 \%) \\
125(17.9 \%)\end{array}$ & $\begin{array}{l}55(34 \%) \\
107(66 \%)\end{array}$ & $\begin{array}{l}31(22.3 \%) \\
108(77.7 \%\end{array}$ & 0.0001 \\
\hline $\begin{aligned} \text { TV watching hours: } & <\text { one hour } \\
& 1-2 \text { hours } \\
& >2 \text { hours }\end{aligned}$ & $\begin{array}{l}99(14.2 \%) \\
200(28.6 \%) \\
400(57.2 \%)\end{array}$ & $\begin{array}{l}29(17.9 \%) \\
56(34.6 \%) \\
77(47.5 \%)\end{array}$ & $\begin{array}{l}14(10 \%) \\
45(32.4 \%) \\
80(57.6 \%)\end{array}$ & 0.111 \\
\hline $\begin{aligned} \text { Playing video games daily: } & \text { Yes } \\
& \text { No }\end{aligned}$ & $\begin{array}{l}249(35.6 \%) \\
450(64.4 \%)\end{array}$ & $\begin{array}{l}52(32.1 \%) \\
110(67.9 \%)\end{array}$ & $\begin{array}{l}59(42.4 \%) \\
80(57.6 \%)\end{array}$ & 0.116 \\
\hline $\begin{aligned} \text { Daily sleeping hours: } & <10 \text { hours } \\
& 10-12 \text { hours } \\
& >12 \text { hours }\end{aligned}$ & $\begin{array}{l}79(11.3 \%) \\
250(35.8 \%) \\
370(52.9 \%)\end{array}$ & $\begin{array}{c}22(13.6 \%) \\
60(37 \%) \\
80(94.4 \%)\end{array}$ & $\begin{array}{c}19(13.6 \%) \\
50(36 \%) \\
70(50.4 \%)\end{array}$ & 0.001 \\
\hline
\end{tabular}

Table (3) shows significant relationship between developing of Obesity and physical inactivity.

Table (4) Odd ratio (95\% CI) for some risk factors among obese children

\begin{tabular}{|c|c|c|c|c|}
\hline Characters & Obese children & $\begin{array}{l}(\mathrm{n}=139) \\
\mathrm{N}(\%)\end{array}$ & $P$ value & Odd ratio $(95 \%$ C I $)$ \\
\hline $\begin{array}{l}\text { Weekly fresh } \\
\text { vegetables and fruits } \\
\text { intake }\end{array}$ & $\begin{array}{l}\text { Once } \\
\text { Twice } \\
\text { More than twice }\end{array}$ & $\begin{array}{c}90(64.7 \%) \\
34(24.5 \%) \\
15(10.8 \%)\end{array}$ & 0.000 & $0.08(.04-0.15)$ \\
\hline Residence & $\begin{array}{l}\text { Rural } \\
\text { Urban }\end{array}$ & $\begin{array}{cc}40 & (28.8) \\
99 & (71.2)\end{array}$ & 0.001 & $0.172(0.115-0.257)$ \\
\hline Mother education & $\begin{array}{l}\text { High } \\
\text { Preparatory } \\
\text { Primary }\end{array}$ & $\begin{array}{l}21(15.1) \\
70(50.4) \\
48(34.5)\end{array}$ & 0.001 & $10.2(6.2-16.6)$ \\
\hline Parental obesity & $\begin{array}{l}\text { No } \\
\text { Father } \\
\text { Mother } \\
\text { Both }\end{array}$ & $\begin{array}{l}4(2.8) \\
20(14.4) \\
30(21.6) \\
85(61.2)\end{array}$ & 0.001 & $132.4(47.06-372.6)$ \\
\hline Feeding & $\begin{array}{l}\text { Breast } \\
\text { Formula } \\
\text { Both }\end{array}$ & $\begin{array}{l}22(15.8) \\
50(36) \\
67(48.2)\end{array}$ & 0.001 & $47.2 \quad(26.48-84.1)$ \\
\hline $\begin{array}{l}\text { Fast food } \\
\text { consumption }\end{array}$ & $\begin{array}{l}\text { Yes } \\
\text { No }\end{array}$ & $\begin{array}{l}73(52.5) \\
66(47.5)\end{array}$ & 0.000 & $6.86 \quad(4.6-10.19)$ \\
\hline Breakfast intake & $\begin{array}{l}\text { Yes } \\
\text { No }\end{array}$ & $\begin{array}{l}50(36) \\
99(64)\end{array}$ & 0.001 & $0.26 \quad(0.17-0.37)$ \\
\hline Physical activities & $\begin{array}{l}\text { Yes } \\
\text { No }\end{array}$ & $\begin{array}{l}31(22.3) \\
108(77.7)\end{array}$ & 0.0001 & $0.06 \quad(0.04-0.09)$ \\
\hline
\end{tabular}

Table (4) shows summary of significant risk factors of Obesity in this study and their odd ratio $(95 \% \mathrm{Cl})$. 


\section{DISCUSSION}

In our study, among 1000 students we found that girls represented $58.3 \%$ (583) and $58.4 \%$ of the participants were from urban. Our study revealed that the overall prevalence of obesity and overweight among children from 6 - 11 years of age was $13.9 \%$ and $16.2 \%$ respectively. In Port Said city the overall prevalence of overweight and obesity among governmental primary school children was $17.7 \%$ and $13.5 \%$ respectively ${ }^{(3)}$. In Sohage, Hadhood et al. ${ }^{(20)}$ reported that out of 711 studied children, 117(16.5\%) were overweight and 104 (14.6\%) were obese. Residing in urban area, having an obese parent or both of them, low level of maternal education, being on feeding formula during early life and lack of fresh vegetables and fruits in diets were significant risk factors for overweight and obesity in the studied children ( $\mathrm{P}$ value $<0.05)$.

In Assuit city, the overall prevalence of obesity among primary school children was $12.28 \%{ }^{(7)}$. In Alexandria, overall prevalence of obesity among school children was 9\% ${ }^{(5)}$. In El-Sharkia, overall prevalence of obesity was $10.7 \%{ }^{\left({ }^{(6)}\right.}$. In Cairo, the obesity prevalence was $22 \%$. These variations might be partially attributed to the difference in the standard curves used for defining obesity and overweight. The overall obesity prevalence in El- Mania was $24.4 \%{ }^{(21)}$.

In Jordon, a study was done on 2131 Jordanian children aged 6-12 years found that $19.4 \%$ were overweight and $5.5 \%$ were obese ${ }^{(22)}$. Difference in prevalence of obesity and overweight between Egyptian and Arabian children could be explained by genetic and dietary variation in addition to differences in socio economic status between Qena governorate and these countries. In the United States, study in 20092010 , revealed that the prevalence of obesity in children and adolescents was $16.9 \%{ }^{(23)}$. In our study, we found that girls were more obese than boys, $\mathrm{p}$ value $<0.05$, $(\mathrm{OR}=7.26,95 \%$ CI: 4.6-10.19). This could be due to reduced activity levels of girls in the school or out of the school. Some of this sex difference could be due to adiposity related to hormonal changes at menarche ${ }^{(24)}$.

Ghazali et al. ${ }^{(25)}$ reported that prevalence of obesity between urban and rural children was not significantly different $(7.2$ vs.7.0\%). Difference in obesity rates between genders was not significant (8.9\% vs. 5.3\%). However, among girls, there was a weakly significant difference in urban-rural obesity rates. Urban girls were less likely to be overweight or obese compared to their rural counterparts $(\mathrm{OR}=0.57$ and $\mathrm{OR}=0.35$ for overweight/obese and obese respectively). This difference is not observed between urban and rural boys. Bahbah et al. ${ }^{(26)}$ in Menoufia reported that the prevalence of obesity among female children was $11.9 \%$, which is higher than male children $7.8 \%$. We found that $71.2 \%$ of the obese children were from urban areas $(\mathrm{P}$ value $=0.001),(\mathrm{OR}=0.172,95 \%$
CI: 0.115- 0.257). This result agrees with results of ElShafie et al. (5) who studied the prevalence of overweight and obesity in primary school children living in Alexandria governorate and found that the prevalence of overweight and obesity among urban children was 18.4 and $10.1 \%$ respectively, which was higher than among rural children which represented 12.1 and $5.6 \%$, respectively.

Badawi et al. (3) showed a strong positive correlation between child BMI and mother's and father's BMI ( $p$ value $<0.001$ ). In our study, there was a significant association between the prevalence of overweight and obesity in school children and education of the mother, where mothers of $34.5 \%$ of obese children finished only the primary level of education compared to $15.1 \%$ of mothers of obese children with higher education ( $\mathrm{P}$ value $<0.05),(\mathrm{OR}=$ 10.2, 95\% CI: 6.2- 16.6). Talat and El Shahat ${ }^{(6)}$ in Urban Sharkia Governorate, Egypt concluded that the prevalence of overweight and obesity was high in children whose parent level of education was low. These results disagree with the study done in El-Mania by Hassan et al. ${ }^{\text {(22) }}$, which showed that the higher the level of parents' education, the higher the prevalence of overweight and obesity. In the present study, $41.1 \%$ of overweight children and $33.1 \%$ of obese children received feeding formula compared to $6.1 \%$ and $3.2 \%$ of overweight and obese children respectively were breast fed (P value <0.05) (OR $=47.2$, $95 \%$ CI: 2684.1). This significant association was also reported by several previous studies which reported the protective role of breast feeding against childhood overweight and obesity. Breastfeeding has been reported as being a potentially protective factor against weight gain in childhood, which is important because overweight children are at risk of becoming overweight adults.

It also agree with the study done by Hassan $\boldsymbol{e t}$ al. (27) among a sample of Egyptian Children, which showed that the prevalence of overweight and obesity in primary school children was 10.7 and $21.3 \%$ respectively in urban children, which was higher than in rural children 12.5 and $12.5 \%$ respectively. It also agrees with the study done by Bahbah et al. ${ }^{(26)}$ in Menoufia, which revealed that the prevalence of overweight and obesity was $18.3 \%$ and $15 \%$ respectively, which was higher than that showed among rural children, which was $7.1 \%$ and $4.8 \%$ respectively with a significant difference. This difference could be attributed to both dietary variations (absence of fast food restaurants, plenty of fresh fruits and vegetables nearby) and increased physical activity in rural areas as means of transportation are uncommon and children usually walk to schools. We found significant association between obesity among one or both parents and prevalence of obesity and overweight among children ( $\mathrm{p}$ value $=0.001),(\mathrm{OR}=134.4,95 \%$ CI: 47.06 - 372.6). As $92.7 \%$ of the overweight children and 
97.2\% of the obese children had an obese parent or both parents were obese. In addition, Badawi et al. ${ }^{(3)}$ in Port Said city, Egypt showed the significant association ( $p$ value $<0.001$ ) between nutrition during lactation period and BMI, where $36.5 \%$ and $22.3 \%$ of formula-fed children were obese and overweight respectively compared with $5.7 \%$ and $18.1 \%$ of breast-fed children. Another study was conducted in Menoufia, Egypt by Farahat et al. ${ }^{(28)}$ who reported that $41 \%$ of normal children aged 4-6 years were breast-fed compared to $28 \%$ of overweight children. Additionally, they found that $38 \%$ of normal children were bottle-fed, compared to $50 \%$ of overweight children $(\mathrm{P}<0.05)$.

Concerning fast food consumption, our study found a very highly significant association between fast food consumption and obesity $(\mathrm{P}=0.001)$, as the majority of the obese students $(52.5 \%)$ and of the overweight students ( $56.8 \%$ ) used to consume fast food compared to $13.9 \%$ of the non-obese students $(\mathrm{OR}=$ 6.86, $95 \%$ CI: $4.6-10.19)$. These results agree with the results of Badawi et al. ${ }^{(3)}$ in Port Said city, Egypt describing that faulty dietary habits as having more fast food, candy, chocolates, sugary Juices and carbonated beverage led to a higher BMI ( $\mathrm{p}$ value $<0.001$ ) and also agree with results of study published in $\mathbf{2 0 0 6}$ by Malik et al. ${ }^{(29)}$, which showed that fast food consumption was highly associated with obesity in adolescent school students.

Frequency of consumption of fresh fruits and vegetables was a significant risk factor that was detected where $43.2 \%$ of the obese children ate fresh fruits or vegetables once compared to only $10.8 \%$ of those who ate them twice daily with very high statistically significant difference $(\mathrm{P}$ value $=0.0001)$. There are many clear benefits to fruit and vegetable consumption, from childhood onwards in enriching the fiber and micronutrient content of the diet while reducing its energy density. Our results agree with Badawi et al. ${ }^{(3)}$ in Port Said city, Egypt who showed that having more fresh fruits and vegetables had lower BMI measures ( $\mathrm{P}$ value $<0.001$ ). Our results also agree with Epstein et al. ${ }^{(30)}$ in New York State who suggested that increasing fresh vegetables intake is important for childhood obesity prevention and also agree with a study done by Heo $\boldsymbol{e t}$ al. ${ }^{(31)}$ in US that found an inverse association between body mass index (BMI) and fruits \& fresh vegetables intake in children.

Physical inactivity may contribute to the development of obesity in the community and a decline in physical activity means that those who are susceptible to weight gain will be at risk of becoming obese. Our study showed that there was a very highly statistical significant inverse relationship between physical activity and obesity ( $\mathrm{P}=0.001)$, as $77.7 \%$ of the obese students did not practice physical activity, $(\mathrm{OR}=0.06,95 \% \mathrm{CI}: 0.04-0.09)$. This finding is in agreement with Ortega et $\boldsymbol{a l} .{ }^{(32)}$ who studied energy intake and expenditure in obese and non-obese Swedish children \& adolescents and found that physical activity level was significantly higher among the non-obese children ${ }^{(32)}$.

\section{CONCLUSION}

About one out of seven of 6-12 year-old-children in Qena city were obese. Locality of residence, gender, guardian education, obese guardian, feeding formula in early life, bad dietary habits (fast food consumption and missed breakfast) and lack of physical activity were likely to be the predictors of this alarming issue. Societal and public health efforts are needed in order to reduce the burden of disease associated with obesity.

\section{REFERENCES}

1. Vandewater EA, Park SE, Hébert ET, Cummings HM (2015): Time with friends and physical activity as mechanisms linking obesity and television viewing among youth. Int J Behav Nutr Phys Act., 12: 1-11.

2. Gillespie S, Haddad L, Mannar V, Menon P, Nisbett N (2013): The politics of reducing malnutrition: building commitment and accelerating progress. Lancet, 382 (9891): 552-569.

3. Badawi NE, Abo Barakat A, El Sherbini SA, Fawzy HM (2013): Prevalence of overweight and obesity in primary school children in Port Said city. Gaz Egypt Paediatr Assoc., 61: 31-36.

4. Taha AA, Marawan HM (2015): Socio-behavioral Determinants Overweight and Obesity in Egyptian Primary School Children. J Child Adolesc Behav., 3: 236.

5. El-Shafie AM, Hogran HH, Dohein AM (2014): Prevalence of Obesity in Primary School Children Living in Alexandria Governorate. Menoufia Medical Journal, 27: 529-532.

6. Talat MA, El Shahat E (2016): Prevalence of overweight and obesity among preparatory school adolescents in Urban Sharkia Governorate, Egypt Dietz WH. Overweight in childhood and adolescence. Gaz Egypt Paediatr Assoc., 64: 20-25.

7. AbdelKarim A (2017): Influence of Parental and Some Demographic Characteristics on Overweight/Obesity Status among a Sample of Egyptian Children. Open Access Macedonian Journal of Medical Sciences, 4: 348351.

8. Deurenberg $\mathbf{P}$ (2009): Universal cut-off BMI points for obesity are not appropriate. British Journal of Nutrition, 85: 135-136.

9. Wormser D, Kaptoge S, Di Angelantonio E, Wood AM, Pennells L, Thompson A (2011): Separate and combined associations of body-mass index and abdominal adiposity with cardiovascular disease: collaborative analysis of 58 prospective studies. Lancet, 377 (9771): 1085-95.

10. Beguy D, Elung'ata $P$, Mberu B, Oduor C, Wamukoya M, Nganyi B et al. (2015): HDSS profile: the Nairobi urban health and demographic surveillance system (NUHDSS). Int J EpiDemiol., 44: 462.

11. McCabe MP, Waqa G, Dev A, Cama T, Swinburn BA (2013): The role of cultural values and religion on views of body size and eating practices among adolescents from 
Fiji, Tonga, and Australia. Br. J. Health Psychol., 18: 383-394.

12. Park HA, Kang JH, Kim KW, Cho YG, Hur YI, Kim OH (2011): Breakfast Skipping, Related Factors, and Nutrients Intake of 5th Grade Student. Korean J Family Med., 32 (1): 11-20.

13. Mavoa HM, McCabe M (2008): Sociocultural factors relating to Tongans' and Indigenous Fijians' patterns of eating, physical activity and body size. Asia Pac J Clin Nutr., 17: 375-384.

14. Poskitt EM (2014): Childhood obesity in low- and middle-income countries. Paediatr. Int. adolescent Health, 34: 239-249.

15. Kelly KR, Haus JM, Solomon TPJ et al. (2011): A lowglycemic index diet and exercise intervention reduces TNF (alpha) in isolated mononuclear cells of older, obese adults. J Nutr., 141: 1089- 1094.

16. De Vriendt T, Moreno LA, De Henauw S (2009): Chronic stress and obesity in adolescents: scientific evidence and methodological issues for epidemiological research. Nutr Metab Cardiovasc Dis., 19: 511-519.

17. Harvey EL, Glenny A, Kirk SF, Summerbell CD (2010): Improving health professionals' management and the organisation of care for overweight and obese people. https://www.ncbi.nlm.nih.gov/pubmed/10796570

18. Wang J, Thornton JC, Russell M, Burastero S, Heymsfield SB, Pierson RN (2002): Asians have lower BMI but higher percent body fat than do Whites: comparisons of anthropometric measurements. Am J Clin Nutr., 60 (1): 23-8.

19. Ghalli I, Salah N, Hussien F, Erfan M, El- Ruby M, Mazen I et al. (2008): Egyptian growth curves 2002 for infants, children and adolescents. Published aka Sartorio A, Buckler JMH and Marazzi N.Crescere nel mondo. Ferring publisher, https://www.researchgate.net/ publication/303373162

20. Hadhood SESA, Ali RAE, Mohamed MM, Mohammed ES (2017): Prevalence and Correlates of Overweight and Obesity among School Children in Sohag, Egypt. Open Journal of Gastroenterology, 7: 7588.

21. Hafez AS, EL Amady MY, Hassan NE (2004): Obesity Profile among Primary School Children in Cairo. Egypt Journal of Community Medicine, 18: 99-107.

22. Hassan NE, El-Masry SA, Farid T, Khalil A (2017): Influence of Parental and Some Demographic
Characteristics on Overweight/Obesity Status among a Sample of Egyptian Children. Open Access Macedonian Journal of Medical Sciences, 4: 66-73.

23. Ogden CL, Carroll MD, Kit B, Flegal KM (2012): Prevalence of Obesity and Trends in Body Mass Index among US Children and Adolescents, 1999-2010. American Medical Association, 307: 491-497.

24. Abraham S, Boyd C, Lal M, Luscombe G, Taylor A (2009): Time since menarche, weight gain and body image awareness among adolescent girls: onset of eating disorders. Journal of Psychosomatic Obstetrics and Gynaecology, 30 (2): 89-94.

25. Ghazali SM, Kamaluddin MA, Said I, Isa MR, Ghazali IMM, Idris N(2006): Obesity among school children in Kuala Selangor. A cross sectional study. Tropical Medicine, 23 (2): 148 -154.

26. Bahbah MH, Slama ESI, Ramadan AEM, Abo Zeed MA (2015): Prevalence of Obesity and Overweight in Primary School Children Living in Menoufia covernorate, Menouf District. Benha Medical Journal, 32: 73-77.

27. Hassan NE, El-Masry SA, Farid T, Khalil A (2016): Influence of Parental and Some Demographic Characteristics on Overweight/Obesity Status among a Sample of Egyptian Children. Open Access Macedonian Journal of Medical Sciences, 4: 342-347.

28. Farahat MA, Mechael A, Abu-Salem M (2003): Prevalence of obesity among preschool children in Menofia, Egypt. Arab Journal of Food and Nutrition, 8: 107-118.

29. Malik VS, Schulze MB, Hu FB (2006): Intake of sugarsweetened beverages and weight gain: a systematic review. Am J Clin Nutr., 84: 274-288.

30. Epstein LH, Paluch RA, Beecher MD, Roemmich JN (2008): Increasing healthy eating vs. reducing high energy-dense foods to treat pediatric obesity. Obesity, 16: 318-26.

31. Heo M, Kim RS, Wylie-Rosett J, Allison DB, Heymsfield SB, Faith MS (2011): Inverse association between fruit and vegetable intake and BMI even after controlling for demographic, socioeconomic and lifestyle factors. Obesity Facts, 4: 449-55.

32.Ortega F, Ruiz J, Sjostrom M (2007): Physical activity, overweight and central adiposity in Swedish children and adolescents: the European Youth Heart Study. Int J Behav Nutr Phy., 4: 61-6. 